\title{
3D-seismic imagery of mega-scale glacial lineations and flow-switching by ice streams on the Norwegian continental shelf
}

\author{
J. A. DOWDESWELL ${ }^{1 *}$ D. OTTESEN ${ }^{2} \&$ L. RISE ${ }^{2}$ \\ ${ }^{1}$ Scott Polar Research Institute, University of Cambridge, Cambridge CB2 1ER, UK \\ ${ }^{2}$ Geological Survey of Norway, Postboks 6315 Sluppen, N-7491 Trondheim, Norway \\ *Corresponding author (e-mail:jd16@,cam.ac.uk)
}

Streamlined glacial landforms, produced by deformation of soft sediments at glacier beds (Dowdeswell et al. 2004; Ó Cofaigh et al. 2005; King et al. 2009), provide clear evidence of the direction of ice-flow at the time of their formation (e.g. Ottesen et al., 2005; Livingstone et al. 2012). Where sets of streamlined landforms are present at or close to the seafloor, swath-bathymetric imagery enables the reconstruction of multiple phases of ice-flow (e.g. Greenwood et al. 2012). In many cases, however, key morphological evidence is buried on palaeo-shelves within the Quaternary glacial sedimentary record (Fig. 1c-d), and can only be analysed by tracing these buried horizons in 3D-seismic datasets (Dowdeswell et al. 2007).

\section{Description}

On the Norwegian shelf, more than a $1 \mathrm{~km}$ thickness of Quaternary glacier-influenced sediments has built up over the last $2.7 \mathrm{M}$ yr as the Naust Formation (e.g. Dahlgren et al. 2002; Rise et al. 2005). At or close to the seafloor of both large fjords and cross-shelf troughs, 3D-seismic and swath-bathymetric imagery show highly elongate streamlined submarine landforms (Fig. 1a-b). Within the Naust Formation, at burial depths of 100 to $200 \mathrm{~m}$, similar streamlined sedimentary landforms have been identified on seaward-dipping horizons that represent former continental shelf surfaces now preserved within the stratigraphic record (Fig. 1c-d). These streamlined landforms, found both at the seafloor and at depth within the Quaternary sediments, are only a few metres in height, tens to a hundred or so metres wide, spaced a few hundred metres apart, and are continuous for kilometres in length (Fig. 1a-d). Note that the streamlined landforms are least well-pronounced in Figure 1d. This is probably linked to their greater burial depth and difficulties in tracing the buried-shelf surface.

The streamlined landforms at the seafloor are orientated parallel to the long-axes of the cross-shelf trough of Trænadjupet and the adjacent Vestfjorden (Fig. 1a-b). By contrast, the long-axes of buried elongate landforms imaged in two 3D-seismic cubes to the south of Trænadjupet are orientated almost orthogonal to those in the trough itself (compare the landform orientations in Fig. 1c-d with those in Fig. 1a), indicating a major shift in the direction of past ice flow.

\section{Interpretation}

The streamlined sedimentary landforms imaged on the Norwegian margin are similar in dimensions to elongate landforms interpreted as mega-scale glacial lineations (MSGLs) from many Late Quaternary glacier-influenced terrestrial and marine environments (e.g. Clark 1993; Livingstone et al. 2012). The features are therefore interpreted as MSGLs, formed by soft-sediment deformation at the beds of modern (King et al. 2009) and former ice streams (Dowdeswell et al. 2004; Ó Cofaigh et al. 2005; Ottesen et al. 2005).

Using the presence of MSGLs to infer the extent of ice on the shelf, ice appears to have flowed out of major fjords and cross-shelf troughs, such as Vestfjorden, Trænadjupet and Sklinnadjupet (Fig. 1e-f), to reach the shelf edge a number of times during Mid/Late Quaternary glaciations in particular (Ottesen et al. 2005). The delivery of sediments from these ice streams has led to the build-up of major depocentres along this margin and to shelf progradation of over $100 \mathrm{~km}$ (e.g. Dahlgren et al. 2002; Rise et al. 2005; Dowdeswell et al. 2006).

The orientation of the MSGLs can also be used to infer ice-flow directions for the last full-glacial landforms preserved close to the seafloor (Fig. 1a-b) and for similar features within buried sediments representing the penultimate or Saalian glaciation (Fig. 1c-d). The resulting ice-stream flow-lines are mapped in Figure 1e. It can be seen that, whereas ice flowed out of Vestfjorden and through Trænadjupet during the Late Weichselian glaciation (Ottesen et al. 2005), it flowed southwards and then westwards in the earlier Saalian glaciation (Fig. 1e; Dowdeswell et al. 2006). This represents a major switch in ice-stream flow direction between the two glaciations. The switch may be related to the filling of accommodation space to the south of Trænadjupet during the Saalian, with the resulting relatively shallow bank deflecting ice-stream flow into Trænadjupet during renewed cross-shelf glaciation in the Weichselian (Dowdeswell et al. 2006).

\section{References}

CLARK, C. D. 1993. Mega-scale glacial lineation and cross-cutting ice-flow landforms. Earth Surface Processes and Landforms, 18, 119.

DAHLGREN, K. I. T., VORREN, T. O. \& LABERG, J. S. 2002, Late Quaternary glacial development of the mid-Norwegian margin $65-68^{\circ} \mathrm{N}$. Marine and Petroleum Geology, 19, 1089-1113.

DOWDESWELL, J. A., Ó COFAIGH, C. \& PUDSEY, C. J. 2004. Thickness and extent of the subglacial till layer beneath an Antarctic paleo-ice stream. Geology, 32, 13-16.

DOWDESWELL, J. A., OTTESEN, D. \& RISE, L. 2006. Flow-switching and large-scale deposition by ice streams draining former ice sheets. Geology, 34, 313-316.

DOWDESWELL, J. A., OTTESEN, D., RISE, L. \& CRAIG, J. 2007. Identification and preservation of landforms diagnostic of past icesheet activity on continental shelves from three-dimensional seismic evidence. Geology, 35, 359-362.

GREENWOOD, S. L., GYLLENCREUTZ, R., JAKOBSSON, M. \& ANDERSON, J. B. 2012. Ice-flow switching and East/West Antarctic Ice Sheeet roles in glaciation of the western Ross Sea. Geological Society of America Bulletin, 124, 1736-1749.

KING, E. C., HINDMARSH, R. C. A. \& STOKES, C. R. 2009. Formation of mega-scale glacial lineations beneath a West Antarctic ice stream. Nature Geoscience, 2, 585-588. 
LivingStONE, S. J., Ó COFAIGH, C., STOKES, C. R., HILlENBRAND, C.-D., VIELI, A. \& JAMIESON, S. S. R. 2012. Antarctic palaeo-ice streams. Quaternary Science Reviews, 111, 90-128.

Ó COFAIGH, C., DOWDESWELL, J.A., et al. 2005. Flow dynamics and till genesis associated with a marine-based Antarctic palaeo-ice stream. Quaternary Science Reviews, 24, 709-740.

OTTESEN, D., RISE, L., KNIES, J., OLSEN, L. \& HENRIKSEN, S. 2005. The Vestfjorden-Traenadjupet palaeo-ice stream drainage system, mid-Norwegian continental shelf. Marine Geology, 218, 175-189.

RISE, L., OTTESEN, D., BERG, K. \& LUNDIN, E. 2005. Large-scale development of the mid-Norwegian margin during the last 3 million years. Marine and Petroleum Geology, 22, 33-44.

Fig. 1. Mega-scale glacial lineations (MSGLs) and flow-switching between glaciations on the Norwegian margin (modified in part from Dowdeswell et al. 2006). (a) Late Weichselian sediments at the modern seafloor of Trænadjupet (imaged in 3D-seismic cube ST9404). Lines running WSW-ENE across the image are artefacts. (b) Multibeam image of the seafloor of Vestfjorden. Acquisition system Kongsberg EM1002. Frequency $95 \mathrm{kHz}$. Grid-cell size $50 \mathrm{~m}$. (c) Buried surface with MSGLs approximately $100 \mathrm{~m}$ deep within the Quaternary Naust Formation (3D-seismic cube NLGS-95). (d) Buried surface with MSGLs about $200 \mathrm{~m}$ deep within the Naust Formation (3D-seismic cube NNE-2000). (e) Map of changing ice-stream flow directions on the mid-Norwegian shelf implied by the changing orientation of MSGLs in panels a-d (located in Fig. 1e). Vestfjorden is VF, Trænadjupet is TD and Sklinnadjupet is SD. Red lines are inferred ice-flow directions of Elsterian/Saalian and white lines are for Late Weichselian ice streams. (f) Location of study area (red box; map from IBCAO v. 3.0). 


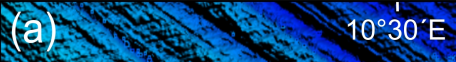

(b) $\quad 60^{30} \mathrm{E}$

$N=$
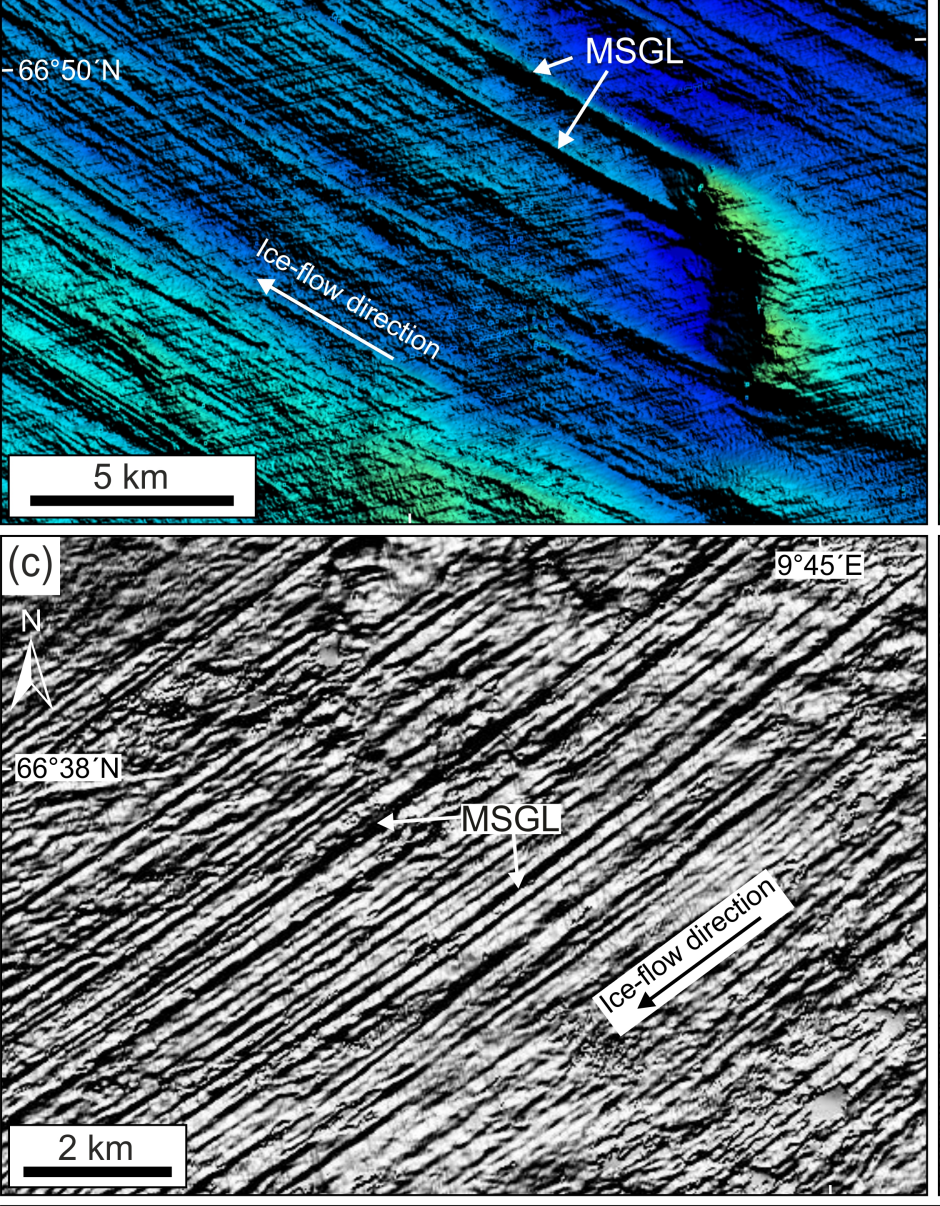

(e) $\begin{array}{r}\square \\ 2800 \quad 0 \mathrm{~m}\end{array}$

Norwegian

Sea

$-68^{\circ} \mathrm{N}$

$-67^{\circ} \mathrm{N}$

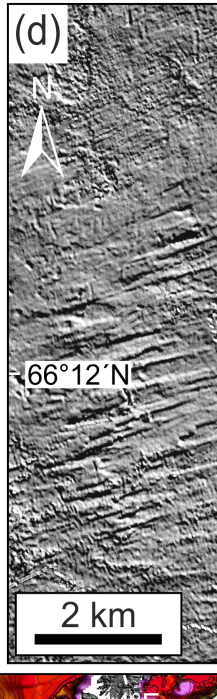

$9^{\circ} 10^{\prime} \mathrm{E}$

in

$5 \mathrm{~km}$ -

$10^{\circ} \mathrm{E}$

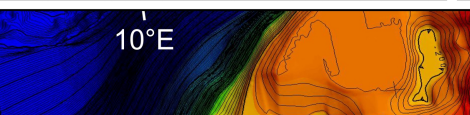

(

6) VF

- 2010
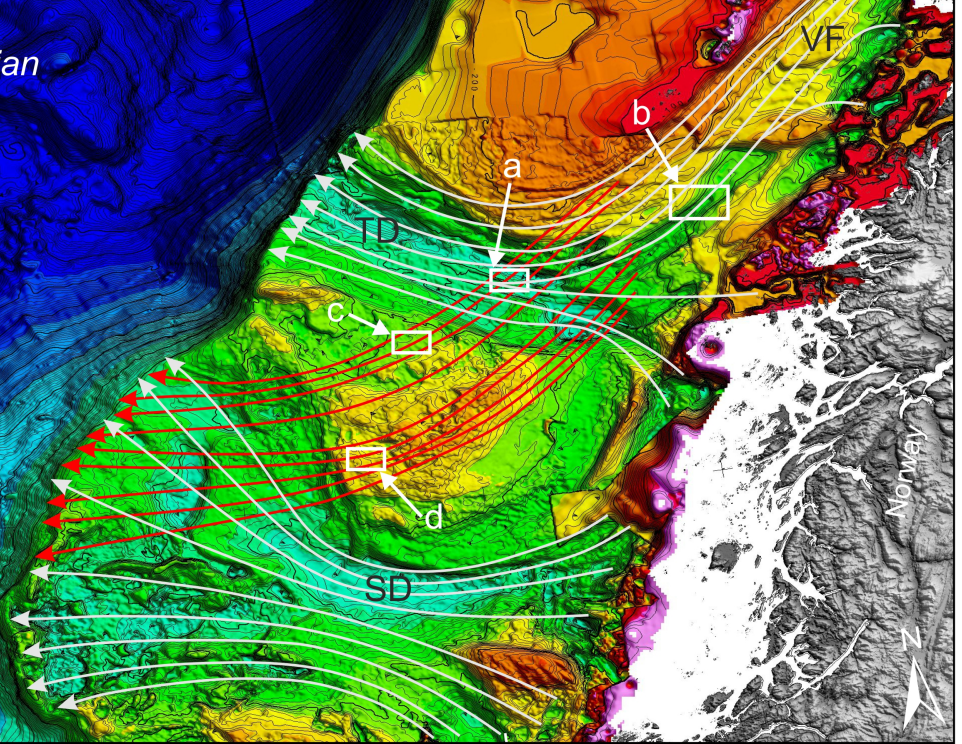

(f)

Barents Sea 